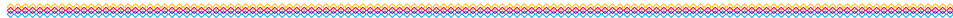

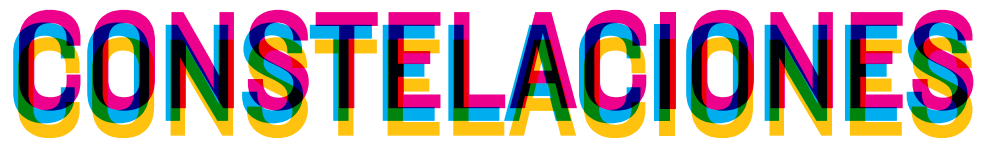

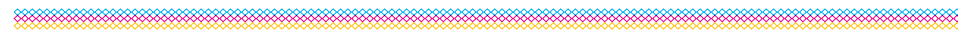


CONSTELACIONES nº6, mayo 2018

Revista de Arquitectura de la Universidad CEU San Pablo

Architecture Magazine of CEU San Pablo University

Periodicidad anual

Annual periodicity

COMITÉ DE REDACCIÓN EDITORIAL COMMITTEE

\section{Dirección Directors}

Juan García Millán

Santiago de Molina

Jefa de Redacción Editor in Chief

Covadonga Lorenzo Cueva

Secretario de Redacción Editorial Clerk

Rodrigo Núñez Carrasco

Maquetación y producción Design and production

Clara Martínez-Conde Rubio

Julia Ruiz-Cabello Subiela

Responsable Web Web Page Manager

María Isabel Castilla Heredia

Diseño Original Original Design

Juan Roldán Martín

\section{CONSEJO EDITORIAL EDITORIAL BOARD}

Beatriz Colomina. School of Architecture, Princeton University, New Jersey

Carmen Díez Medina. Escuela de Ingeniería y Arquitectura, Universidad de Zaragoza

María Antonia Frías Sargadoy. Escuela Técnica Superior de Arquitectura, Universidad de Navarra

Juan Miguel Hernández Léon. Escuela Técnica Superior de Arquitectura, Universidad Politécnica de Madrid Juan José Lahuerta Alsina. Escuela Técnica Superior de Arquitectura, Universidad Politécnica de Cataluña, Barcelona Eduardo Leira Sánchez. Ex director del Plan General de Ordenación Urbana, Madrid

Joaquín Medina Wamburg. Facultad de Aquitectura Diseño y Urbanismo, Universidad de Buenos Aires

Zaida Muxí Martínez. Escuela Técnica Superior de Arquitectura, Universidad Politécnica de Cataluña, Barcelona José Joaquín Parra Bañón. Escuela Técnica Superior de Arquitectura, Universidad de Sevilla

Víctor Pérez Escolano. Escuela Técnica Superior de Arquitectura, Universidad de Sevilla

Fernando Pérez Oyarzún. Escuela de Arquitectura y Diseño, Pontificia Universidad Católica, Santiago de Chile

Judith Sheine. School of Architecture and Allied Arts, University of Oregon, Portland

Andrés Walliser Martínez. Global Design, New York University, Nueva York

ISSN 2340-177X

Depósito legal M-13872-2013

(c) de los textos, sus autores

(c) de las imágenes autorizadas

(c) Revista Constelaciones

๑) Escuela Politécnica Superior, Universidad CEU San Pablo

Universidad CEU San Pablo

Escuela Politécnica Superior

Urbanización Montepríncipe, s/n

Alcorcón, 28925. Madrid (España)

constelaciones@eps.ceu.es

www.uspceu.es

www.revistaconstelaciones.wordpress.com

Edición Edition

Fundación Universitaria San Pablo CEU

Madrid, España

Impresión Printing

VA Impresores

Impreso en España Printed in Spain

Distribución Distribution

CEU Ediciones

\author{
INDEXACIÓN INDEXING \\ Índices Index \\ Latindex \\ Avery Index \\ ErihPlus \\ MIAR
}

Bases de datos Data bases

Dialnet

Índices en evaluación Evaluation Index

Web of Science

Scopus

Dulcinea

EBSCO

Sherpa Romeo

Los textos que componen Constelaciones se obtienen mediante convocatoria pública. Para que los trabajos recibidos entren en el proceso de selección de los artículos a publicar deben ser trabajos originales no publicados anteriormene, con una extensión recomendada de 3.000 palabras, título, resumen (un máximo de 150 palabras) y palabras clave (un mínimo de cuatro palabras), en español y en inglés. Tras haber cumplido estos requisitos (y los correspondientes incluidos en las normas editoriales de la revista, disponibles para consulta en formato digital desde el comienzo de la convocatoria), tiene lugar un proceso de revisión y evaluación de los artículos previa aceptación de los mismos para su publicación. Para acometer dicho proceso, y con el fin de asegurar la calidad de los contenidos, la revista Constelaciones recurre a evaluadores externos a la institución editora y anónimos (cada artículo es evaluado por dos de ellos) encargados de someter a crítica los mismos. Todos los artículos de investigación publicados en esta revista han pasado por dicho proceso. La recepción de artículos se extendió hasta el 30 de septiembre de 2017. Texts included in Constelaciones are obtained by public announcement. Only original papers that have not been previously published will be included in the process of selection of articles. They should not exceed 3.000 words and should include a title, an abstract (no more than 150 words) and keywords (a minimum of four words), in Spanish and English. After having fulfilled these requirements (and those included in magazine editorial standards, available for consultation from the beginning of the Call for Papers), occurs a process of review and evaluation of articles upon acceptance of them for publication. To undertake this process, and in order to ensure the quality of the contents, Constelaciones turns to external and anonymous evaluators to the institution (each article is evaluated by two of them) responsible for the critic. All the articles published in this journal have undergone this process. The deadline for reception was extended until September 30, 2017.

Todos los derechos reservados. Esta publicación no puede ser reproducida, ni en todo ni en parte, ni registrada, ni transmitida, ni almacenada en ninguna forma ni por ningún medio, sin la autorización previa y por escrito del equipo editorial. En este número se han utilizado algunas imágenes de las que no se ha podido identificar al propietario de los derechos. En estos casos hemos entendido que las imágenes son de libre uso. En caso de identificar alguna de estas imágenes como propia, por favor, póngase en contacto con la redacción de Constelaciones. Los criterios expuestos en los diversos artículos de la revista son responsabilidad exclusiva de sus autores y no reflejan necesariamente los que pueda tener el equipo editoral. El equipo editorial de la revista no se responsabiliza de devolver la información enviada a la redacción a no ser que se le solicite expresamente. All rights reserved. This publication cannot be reproduced, in whole or in part, nor registered, transmitted or stored in any form or by any means, without the written permission of the Editorial team, In this issue some images were used without knowing the owner of the rights. In these cases, we have understood that the images are free of use. In case you identify shared by the editors of this journal. The publisher don't take responsibility for returning submitted material which is not expressly requested. 


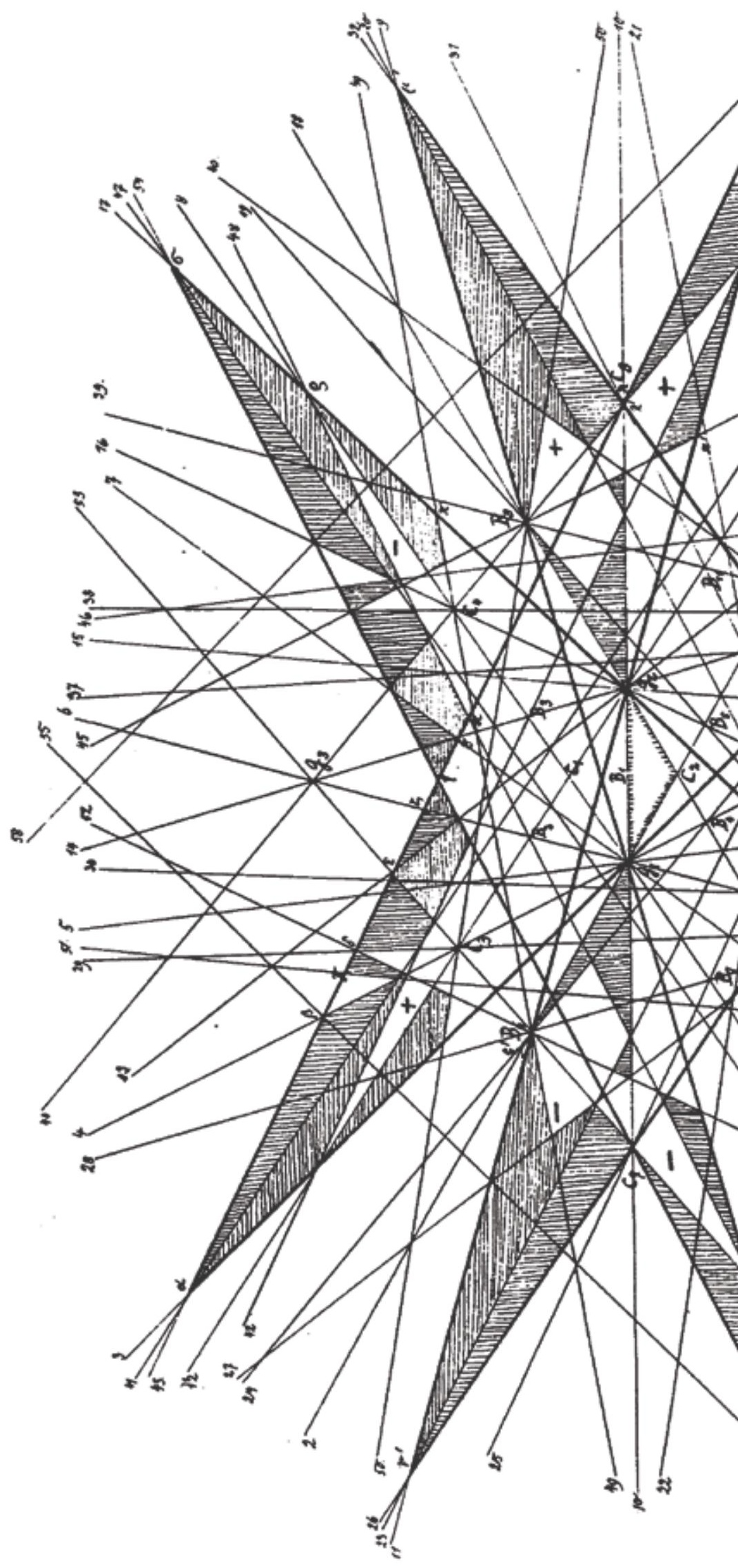




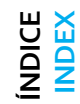

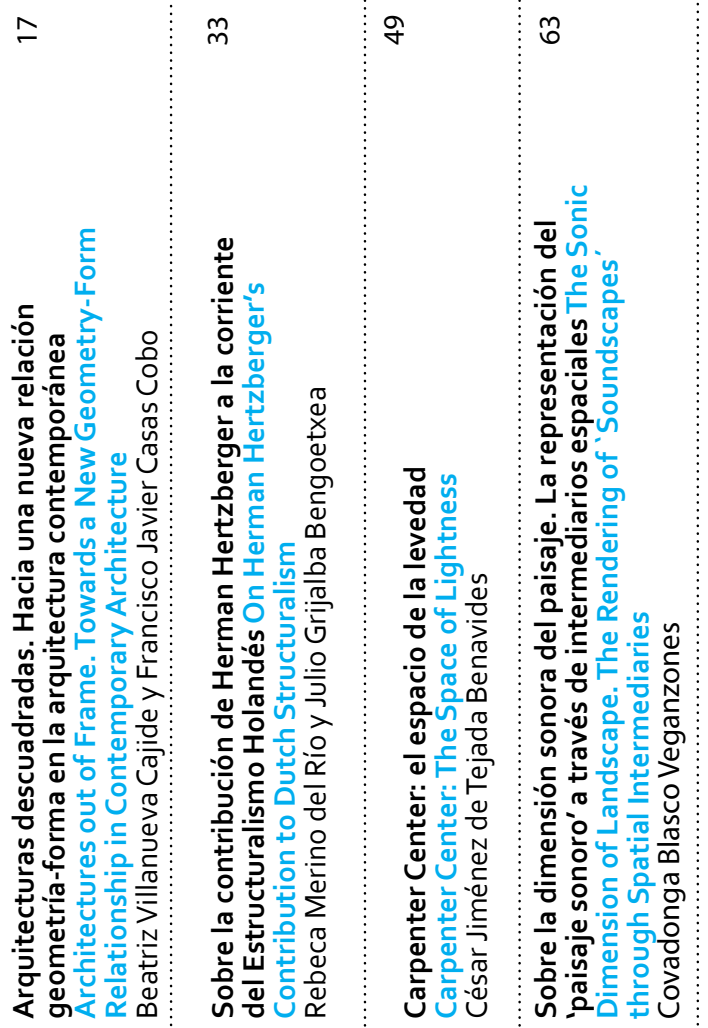

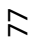

ต

$\leftleftarrows$

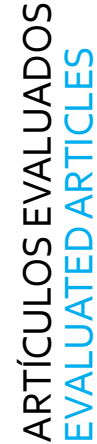

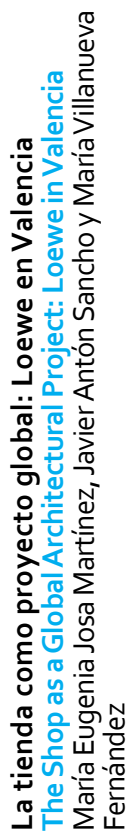

윰 可

틈응

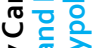

울을

I0

율

동

능

잉이

용요

ब雨

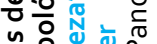

은음

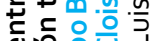

넌은 을겅

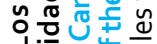

능뭉ㅎㅇㅇㅇㅇ

荇

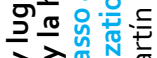

入入⿻

준

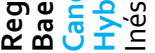
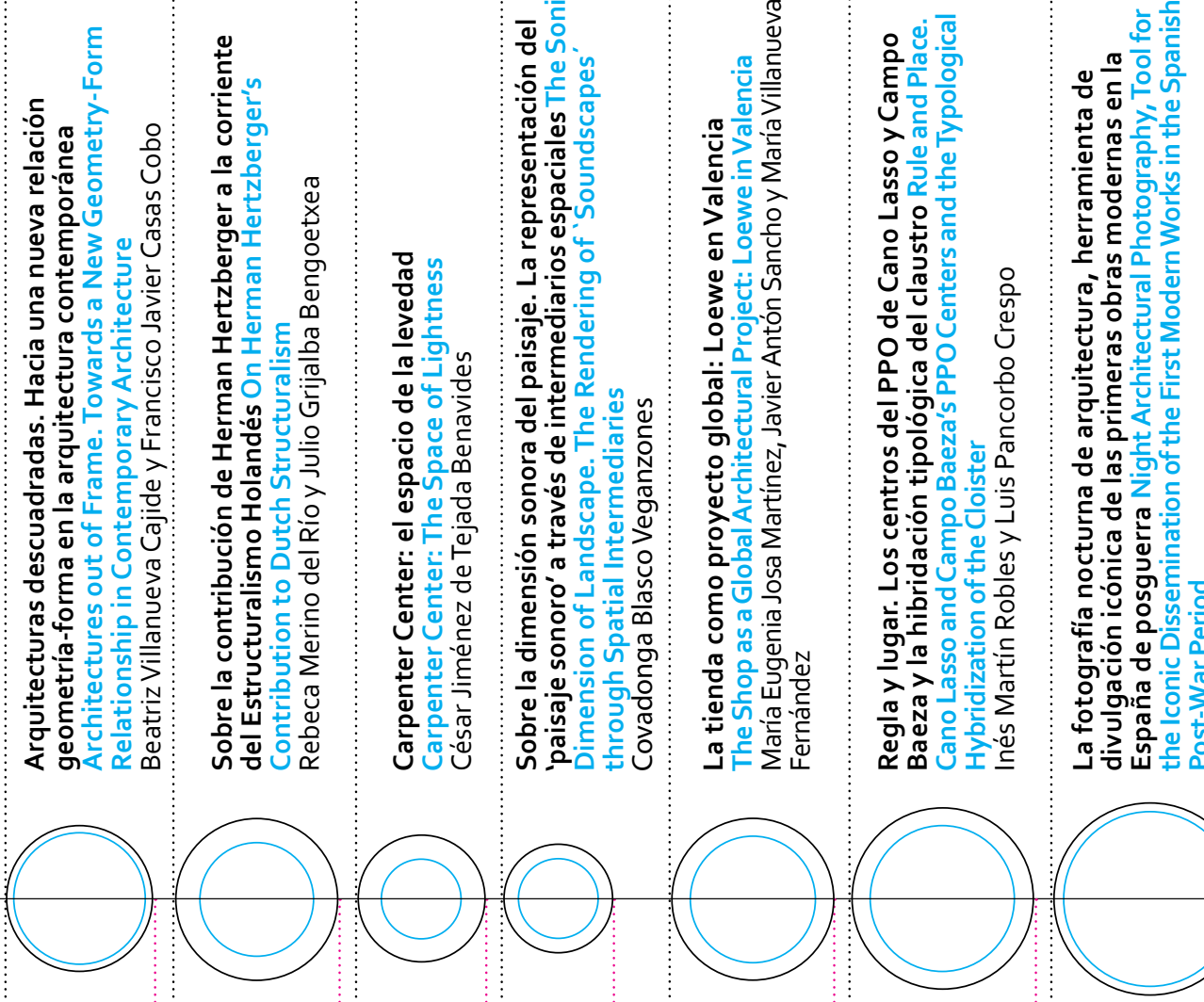

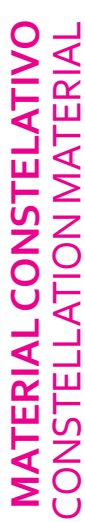

岂㟧

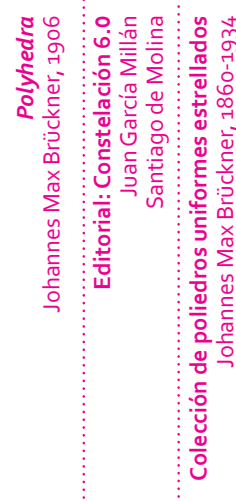

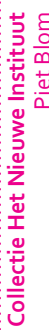
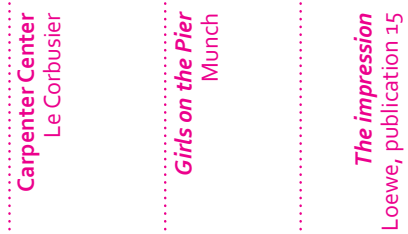

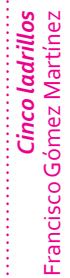

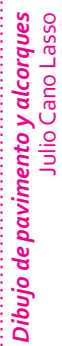

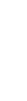

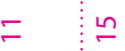

$\bar{m}$

ร

ธ

옹 


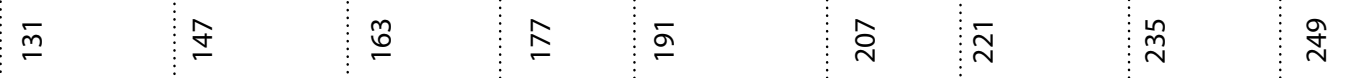

ह단

竞:

을 응

$\frac{\pi}{2} \cup$

을

约

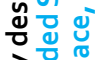

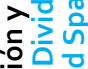

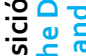

负

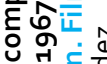

중

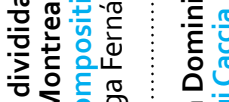

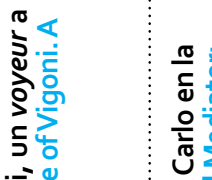

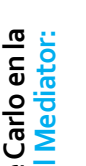

हें

ดั ชั

은 흥영

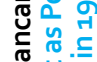

ชั่

ए

ธิ่

过 벙

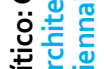

능는

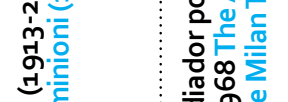

ชั0

हूष

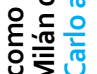

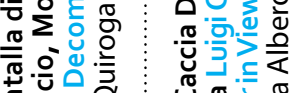

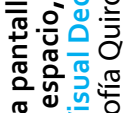

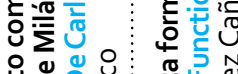

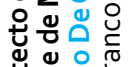

껀

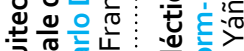

:

혼든 은

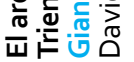

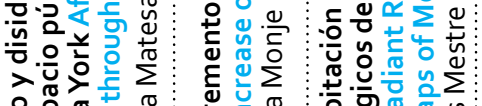

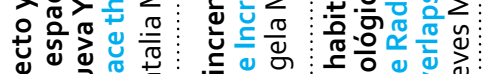

选守之光艺

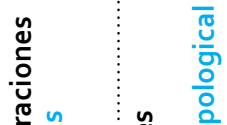

는 흔

กำ $\frac{1}{0} \div$

ถั

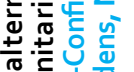

入ว 일

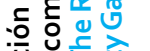

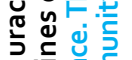

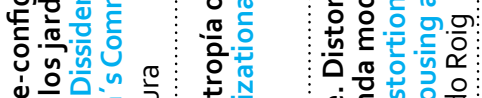

๙

.ํำ $\stackrel{0}{0}$

난.

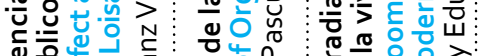

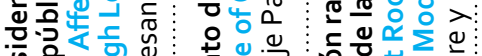

능

త $>\boldsymbol{>}$

ง๋

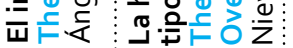
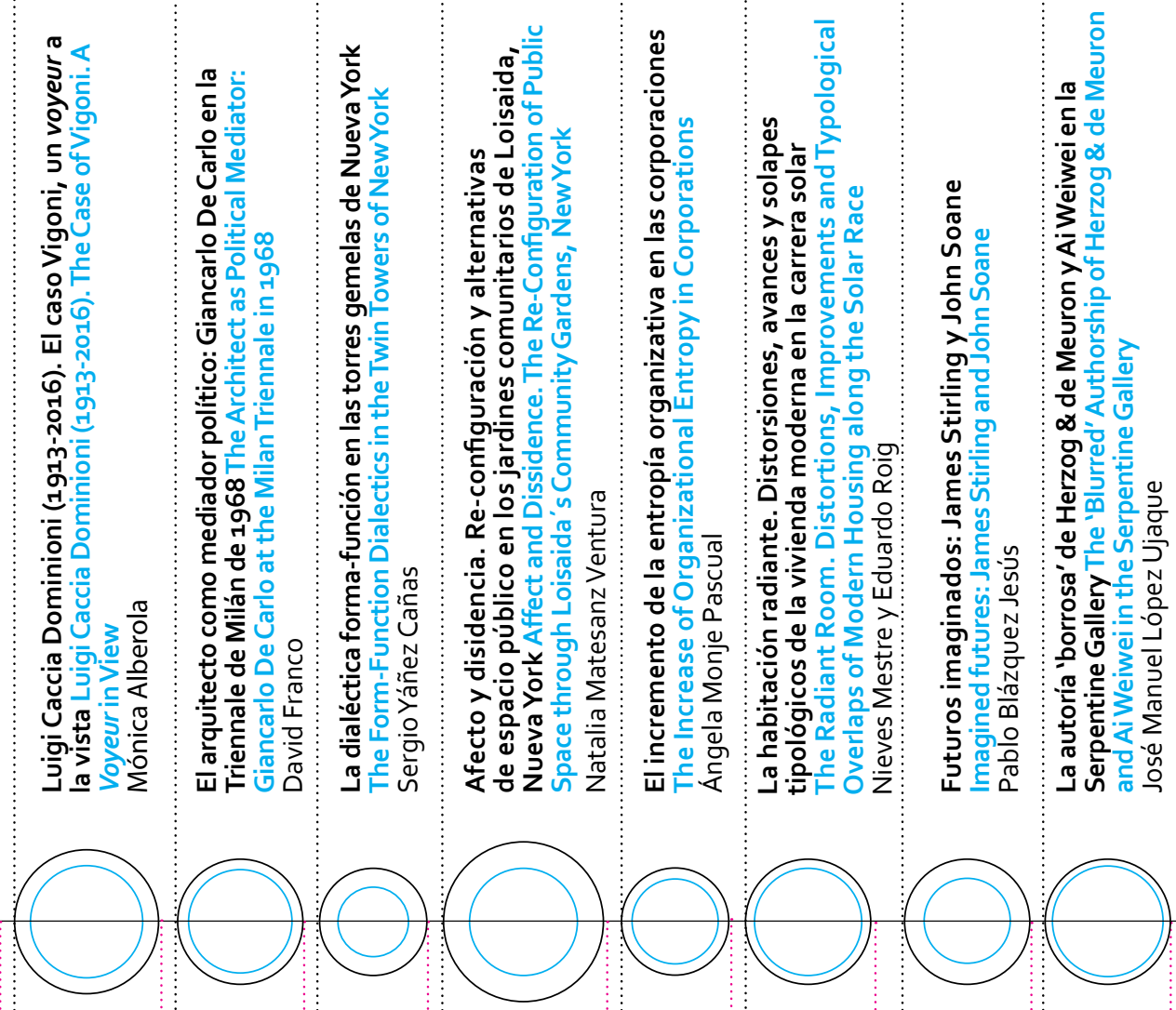

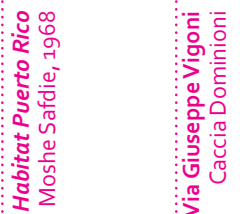

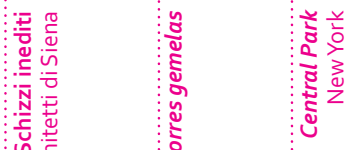

$\sum_{2}^{2}$

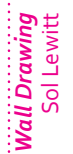

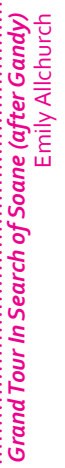

ำ

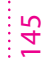

$\stackrel{\circ}{\stackrel{n}{2}}$

$\infty$

ํํำ

$\stackrel{N}{\sim}$

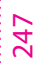

융 గ 


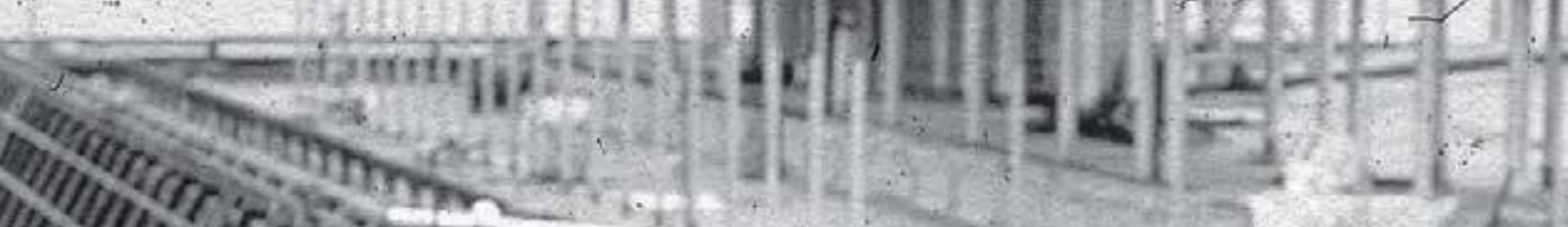

(40,

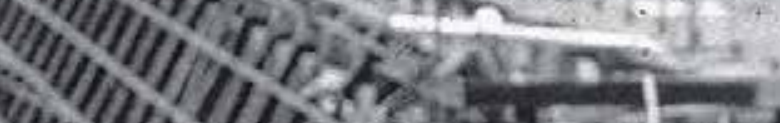

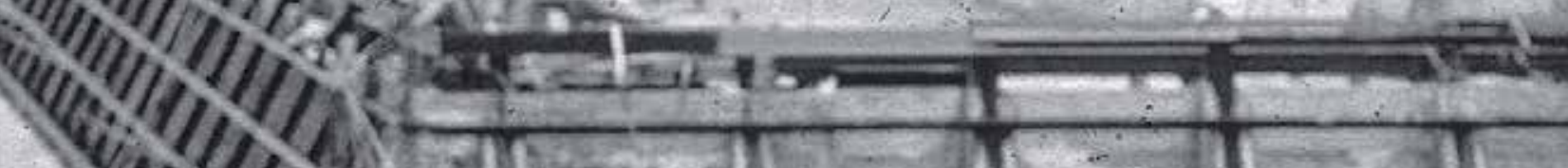

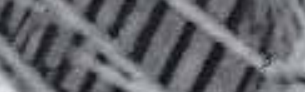

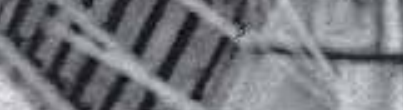
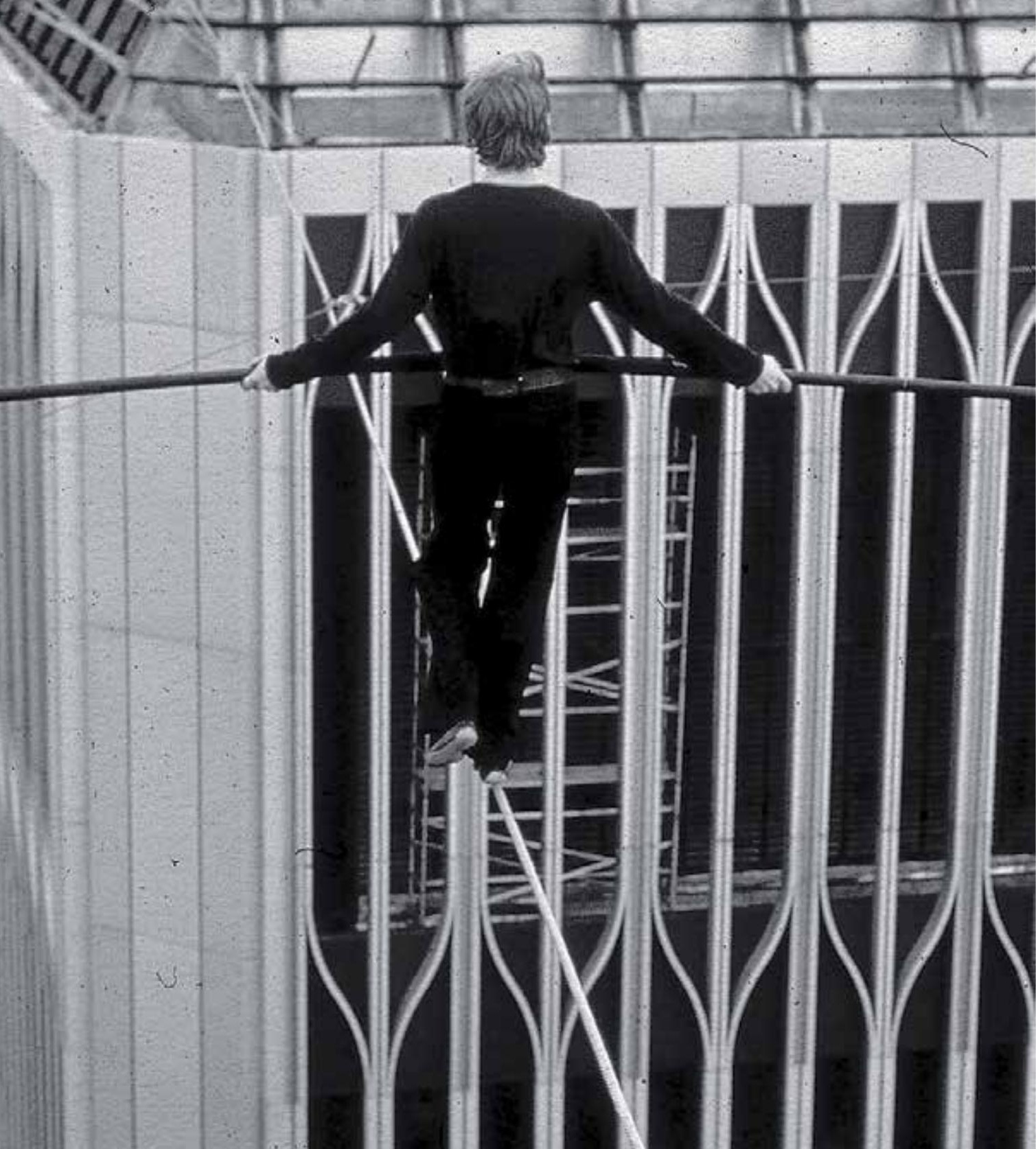


\section{La dialéctica forma-función en las torres gemelas de Nueva York The Form-Function Dialectics in the Twin Towers of New York}

\section{Sergio Yáñez Cañas}

Escuela Politécnica Superior, Universidad CEU San Pablo, Madrid

Traducción Translation Sergio Yáñez Cañas

\section{Palabras clave Keywords}

Torres Gemelas, postmodernismo, dialéctica, forma, función, Mies, Sullivan

Twin Towers, postmodernism, dialectics, form, function, Mies, Sullivan.

\section{Resumen}

El presente artículo expone las limitaciones de una de las componentes de la crítica realizada ante la construcción de las Torres Gemelas del World Trade Center de Nueva York: aquella que identifica abstracción formal e incapacidad comunicativa. Para ello presenta la síntesis de que en las Torres Gemelas se operó entre forma y función como clave para interpretar el programa comunicativo del proyecto. Dado que dicho programa no se ciñó a consideraciones puramente arquitectónicas, para entenderlo se analizarán aquí sus raíces culturales y filosóficas. A través de dicha síntesis se concluye que la capacidad comunicativa de las Torres fue infravalorada, en su momento, desde posiciones excesivamente visualistas. En efecto, parte de la crítica subestimó su capacidad expresiva, a través de un análisis insuficiente de la adscripción arquitectónica, cultural y filosófica de las Torres.

\section{Abstract}

This article describes the limitations of one of the components of the critique made about the construction of New York's World Trade Center Twin Towers: that which identifies formal abstraction with communicative inability. To this end, it presents the dialectical synthesis between form and function that operated in the Twin Towers, as a key to understand the communicative program of the project. As that program was not only about strictly architectonical considerations, its cultural and philosophical roots are analysed here in order to understand it. Through that synthesis, the article concludes that the communicative ability of the Towers was underestimated at the time from excessively visualist positions. Indeed, part of the critique undervalued their communicative ability trough an insufficient analysis of the architectonical, cultural and philosophical adscription of the Towers. 
La dialéctica. Uno de los reproches más frecuentes recibidos por las Torres Gemelas tras su construcción en 1973 fue el de su supuesta atrofia comunicativa. Con especial crudeza lo escribiría Paul Goldberger en 1979: "si [las Torres Gemelas] dicen algo sobre nuestra ciudad, es que nos retiramos a la banalidad cuando hay oportunidad para la grandeza". (1) La guía de la AIA sobre Nueva York las llamaba "monolitos banales y estólidos" (2) y John Tauranac dijo que parecían "más radiadores que edificios". (3) Lewis Mumford las caracterizaría como "un ejemplo del gigantismo sin propósito y exhibición tecnológica, que hoy en día están eviscerando el tejido vivo de toda gran ciudad". (4) Se repiten las referencias a lo inerte, lo inexpresivo y lo banal. No cabe hacer una identificación de las críticas negativas hacia las Torres con la corriente de pensamiento postmoderno, pero tampoco puede ocultarse su afinidad con el less is a bore antimoderno de Robert Venturi. (5) En lo que sigue se argumenta que, al menos en lo que se refiere a las Torres Gemelas, esa correlación entre uno de los principios rectores de la arquitectura moderna (la simplicidad formal) y la inexpresividad, se basa en un análisis puramente visual que infravalora las raíces que cimientan el Racionalismo y Funcionalismo modernos. Para ello, se construye un modelo articulado en torno a una dialéctica entre forma y función, que está más en la línea monista del Idealismo absoluto hegeliano que en la interpretación dicotómica tomista. (Fig. 1)

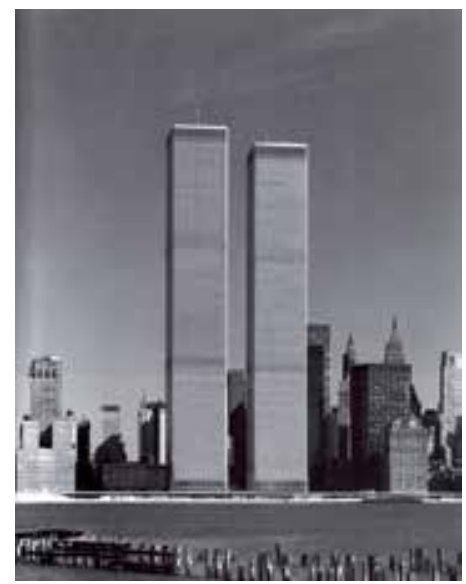

Fig. 1. Las Torres Gemelas en toda su plenitud ortogonal.

Es necesario justificar que las Torres Gemelas constituyan la representación material de esa articulación. En efecto, las Torres funcionan a dos niveles, a los que desde una perspectiva arquitectónica cabe denominar 'forma' y 'función', pero que de hecho, están conformados por múltiples nociones que no solo se adscriben al campo arquitectónico. La 'forma' de las Torres, su simplificación abstracta, se relaciona por su inherente idealización con la razón en un sentido cartesiano: los dos monolitos prismáticos, no solo recurren a lo euclídeo en su reducción ortogonal, sino que la doble referencia a lo paralelo (paralelismo entre los pilares exteriores, por una parte y paralelismo entre las dos Torres, por otra) remite necesariamente a la noción de infinito y con ella a lo ideal, dado que dicho infinito solo puede ser aprehendido por la razón, por el sujeto pensante. Las connotaciones de ese nivel ideal son la

The Dialectics. One of the most frequent criticisms made about the Twin Towers after their construction in 1973 was about their alleged communicative inability. Paul Goldberger formulated it with severity in 1979: "if they say anything at all about our city, it is that we retreat into banality when the opportunity comes for greatness". (1) The AIA Guide to New York City called them "stolid, banal monoliths" (2) and John Tauranac wrote that they seemed "more radiator than building". (3) Lewis Mumford characterized them as an "example of the purposeless gigantism and technological exhibitionism that are now eviscerating the living tissue of every great city". (4) They are often called inert, inexpressive and banal. It is not possible to identify the arguments against the Towers with postmodern thinking nor hide its affinity with the antimodernist "less is a bore" by Robert Venturi. (5) This article argues that (at least referring to the Twin Towers) correlation between one of the guiding principles of modernist architecture (formal simplicity) and inexpressiveness is based upon a strictly visual analysis that undervalues the roots of modernist rationalism and functionalism. In order to do so, it builds up a model around the form-function dialectics which corresponds more with Hegelian monistic absolute idealism than with Thomist dichotomous understanding. (Fig. 1)

It is necessary to justify the Towers as a material representation of that dialectics. Indeed, the Towers worked at two levels that from an architectural perspective can be called form and function, though in fact they also consist of by non-architectural notions: The form of the Towers (their abstract simplicity) relates to reason because of their inherent idealization in a Cartesian way: the two monolithic prisms turn out to be Euclidean not only through their orthogonal simplification but also through their double reference to parallelism (between the pillars and between 
elevación intelectual, la lógica, la equidad y conceptos análogos, pero también una cierta etapa de la humanidad en torno a la Edad Moderna cuyos presupuestos y aportaciones culminan con las propias Torres.

Las Torres representan todo aquello a lo que se opondrá el Relativismo (6) postmodernista. Sus significados connotativos referidos a lo cartesiano en cuanto moderno, racionalista, matemático, positivista y determinista las convierten en representantes del capitalismo de mercado y las críticas negativas cosechadas entre intelectuales interesados en el aspecto social de la arquitectura, como Jane Jacobs o Lewis Mumford, si no lo prueban, sí lo condicen. No cabe relacionar, sin más, la abstracción geométrica de las Torres con una retórica de lo absoluto sin explicar cómo opera esa relación. Si bien la regularidad, simetría y ortogonalidad de las Torres constituyen referencia suficiente a los cuerpos geométricos más simples, hay otro elemento privativo de la arquitectura construida que tiene que ver con su contemplación dinámica, es decir, con su visión en perspectiva desde diferentes puntos. (7) En efecto, se adoptara la posición y distancia que se adoptara, aunque la visión real distara de corresponder a la de un prisma en isometría, el observador sabía automáticamente que la figura percibida era la de un prisma: desde todas las posiciones se contemplaba una forma idéntica. A pesar de que la cercanía deformara aparentemente las relaciones proporcionales entre las partes del edificio y desmintiera el paralelismo, la referencia formal seguía siendo la del prisma. (Fig. 2)

Paradójicamente, en eso coinciden las Torres con la arquitectura antitética (8) de Venturi y los edificios denotativos defendidos por él, como en Las Vegas o el Big Duck; se acerque o se aleje uno de ellos, lo que sigue contemplando es un anuncio o un pato (o en todo caso, un edificio en forma de pato). En ese sentido, la antítesis de las Torres de Yamasaki la constituyen arquitecturas como las de Zaha Hadid o Frank Gehry, que en cambio se sitúan en valores parecidos en lo que a abstracción, ausencia de ornamento y materiales se refiere. Este hecho pone de manifiesto, por una parte, que al hablar de afinidades y desencuentros resulta imprescindible no hablar de

the Towers) which recalls the notions of infinity and idealism. The link between these notions is immediate: infinity is the product of reason more than a tangible reality. That ideal dimension connotes intellectual rigor, logic, equity and so on, but also a specific stage of history known as modern period whose principles and contributions culminate with the Twin Towers.

Postmodernist relativism will oppose what the Twin Towers represent.(6) Their Cartesian, modernist, rationalist, mathematical, positivist and determinist connotative meanings convert them into symbols of market capitalism. The criticism from socially concerned thinkers such as Jane Jacobs or Lewis Mumford is consistent with it. Connecting the geometric abstraction in the Towers with supreme and absolute notions requires further explanation. Although regularity, symmetry and orthogonalithy refer by themselves to the simplest geometric figures, there is an element which exclusively belongs to built architecture: its view from different points. (7) Indeed, even though from certain positions the perception was not that of an isometric regular prism, the observer knew that the figure perceived was a regular prism: they were perceived the same no matter the distance or position. (Fig. 2)

Paradoxically, the Towers shared that characteristic with the antithetic architecture (8) advocated by Venturi, as in Las Vegas or the Big Duck: no matter the distance, the observed object kept being an advertisement or a duck (or, at least, a duck-shaped building). In that sense, the buildings designed by Zaha Hadid or Frank Gehry are the antithesis of the Towers by Yamasaki, whereas they are similar to them regarding abstraction, lack of ornament and materials. That fact 
los movimientos arquitectónicos como un todo, sino aclarar qué vertiente o faceta se está analizando, y por otra problematiza los vínculos entre Postmodernismo y Deconstructivismo.

La 'función' de las Torres, en cuanto rascacielos de oficinas en el Bajo Manhattan, se relaciona de manera inequívoca con la praxis capitalista, tanto por la especulación inmobiliaria asociada con el alquiler de sus oficinas, como por la actividad económica realizada por los trabajadores de cuello blanco localizados allí, pero también, si tenemos en cuenta el proyecto de forma global, con las necesidades de trasporte masivo en una ciudad tan densa como Nueva York. Si el diseño de las Torres apela a lo ideal, su uso remite a lo real. Si su visión está necesariamente abierta al público -y es reproducida por múltiples imágenes a su vez reproducibles- su uso -más allá de miradores y restaurantes- es eminentemente privado. Si su forma enlaza con el arte a través de la arquitectura, su uso tiene que ver con el comercio de mercancías inicial y teóricamente de capitales, según pasaran los años. Este segundo nivel, el del hecho, está constituido por el contenido de las Torres; se refiere a aquello sin lo que las Torres serían una dupla de esculturas monumentales, un par de monolitos idénticos. Se puede esquematizar esta doble dimensión: (9)

$\begin{array}{llll}\text { FORMA } & \text { FUNCIÓN } & \text { FORM } & \text { FUNCTION } \\ \text { ideal } & \text { real } & \text { ideal } & \text { real } \\ \text { razón } & \text { praxis } & \text { reason } & \text { praxis } \\ \text { infinita } & \text { finita } & \text { infinite } & \text { finite } \\ \text { inorgánica } & \text { orgánica } & \text { inorganic } & \text { organic } \\ \text { arte } & \text { comercio } & \text { art } & \text { trade } \\ \text { pública } & \text { privada } & \text { public } & \text { private } \\ \text { universal } & \text { particular } & \text { universal } & \text { particular } \\ \text { trascendentalista } & \text { materialista } & \text { trascendentalist } & \text { materialist } \\ \text { destino } & \text { misión } & \text { destiny } & \text { mission }\end{array}$

implies, firstly, that discussing similarities and disagreements requires considering architectonical styles not as a whole but as a complex reality, and secondly it makes the relation between postmodernism and deconstructivism problematic.

The function of the Towers (office buildings in Downtown) is unmistakably connected with capitalist praxis, both because of the property speculation associated with rental and because of the economic activity carried out by their white-collar tenants, but also, if one considers the project in a comprehensive manner, because of the mass transport needs of a city as dense as New York. The design of the Towers invokes idealism, while their operation invokes realism. Their view is inevitably open to the public (and it is successively reproduced through images), while their use (apart from viewpoints and restaurants) is eminently private. Their form is linked to art through architecture, while their function is linked with trade, both of goods at the beginning and of capitals later. This second level, function, is formed by the content of the Towers: it is related to everything which prevents the Towers from being just a pair of monumental sculptures, a couple of identical monoliths. A schematization of that double dimension is included above. (9)

The Synthesis. Rem Koolhaas writes: "Businessmen have to admit it: manhattanism is the only program through which efficacy meets the sublime". (10) The characterization of the links between both levels is more important than that of the levels themselves: those relations between levels transform them into the synthesis of a dialectics instead of letting them be independent categories. They are not a univocal concept, but those links between levels are multiple and work under an inductive dynamic from particular to general. Firstly, the arithmetical logic takes part both in the necessary calcula- 


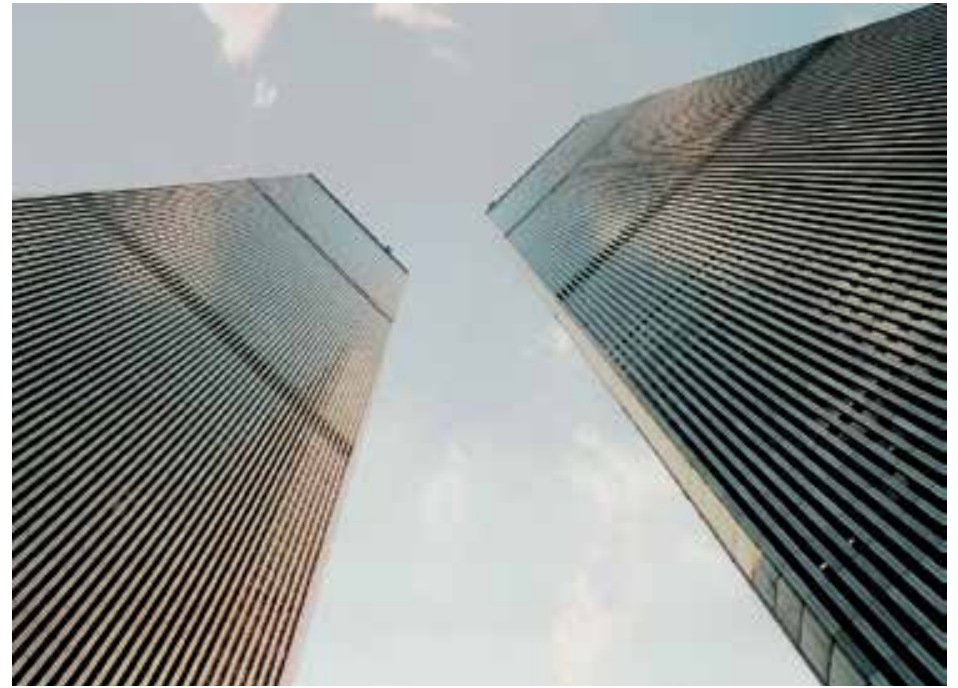

La síntesis. Escribe Rem Koolhaas: "Los hombres de negocios tienen que admitirlo: el manhattanismo es el único programa en el que la eficacia se cruza con lo sublime". (10) Más importante que la caracterización de los niveles es la de los lazos que los articulan; esas relaciones entre planos que los transforman en síntesis de una dialéctica, en lugar de mantenerlos como categorías independientes. Tampoco en este caso se trata de un concepto unívoco, sino que los puentes entre ambos niveles se establecen de forma múltiple. La relación de esta realidad poliédrica se hará bajo una dinámica inductiva, caminando desde los particulares al factor común conformado por ellos. Cabe mencionar, en primer lugar, la lógica aritmética, que participa tanto en los cálculos necesarios para levantar los edificios como en las herramientas básicas de las actividades empresariales llevadas a cabo en su seno. Ese recurso compartido a lo matemático es especialmente significativo: en primer lugar, el propio lenguaje matemático engloba tanto el
Fig. 2. Perspectiva de las Torres Gemelas desde su plaza central.

tions to erect the buildings and in basic tools of entrepreneurial activity executed inside them. This double reference to mathematics is especially significant: in the first place, the language on mathematics encompasses both universal and unapplied algebra and numeric and practical arithmetic. In the second place, mathematics has a legitimizing role in politics (elections results) and in academic research (even in social sciences).

The outspoken opposition to formalist from modernist architecture (11) is also relevant to this convergence between the particular and the universal: although the term 'modernist architecture' subsumes a group of different architectonical trends and programs, revaluation of function before form is a common denominator of all of them. The architect Louis H. Sullivan had written in 1896: "Whether it be the sweeping eagle in his flight, or the open apple-blossom, the toiling work-horse, the blithe swan, [...] form ever follows function, and this is the law. Where function does not change, form does not change [...] It is the pervading law of all things organic and inorganic, of all things physical and metaphysical, of all things human and all things superhuman, of all true manifestations of the head, of the heart, of the soul, that the life is recognizable in its expression, that form ever follows function. This is the law" (12)

The fact that "form follows function" became the motto of functionalism and therefore the most known part of the upper citation involves some problems around the same notion. In the first place, the citation shows that modernist architecture was based upon principles and criteria that surpass strictly architectonical conceptions: beyond its validity (which is a difficult debate), its intellectual solidity (less controversial) is based on a multidisciplinarity that architecture is recently 
álgebra (universal y no aplicada) como la aritmética (numérica y de índole práctica); en segundo, las matemáticas cumplen un papel legitimador en política (resultados electorales) o en la investigación académica (incluso en el campo de las ciencias sociales).

También es relevante para esta convergencia entre lo particular y lo universal, la abierta oposición de la arquitectura moderna ante el Formalismo: (11) a pesar de que bajo la expresión Movimiento Moderno se agrupan en realidad diferentes tendencias y programas arquitectónicos, uno de los denominadores comunes a todas ellas es la revalorización de la función con respecto a la forma. En 1896 el arquitecto Louis H. Sullivan había escrito: "Ya sea el águila deslizándose en su vuelo o la flor del manzano, el esforzado caballo de tiro, el despreocupado cisne, [...] la forma siempre sigue a la función y ésta es la ley. Donde la función no cambia, la forma no cambia. [...] Esta es la ley que impregna todas las cosas orgánicas e inorgánicas de todas las cosas físicas y metafísicas, de todas las cosas humanas y sobrehumanas, de todas las verdaderas manifestaciones de la cabeza, del corazón, del alma; que la vida es reconocible en su expresión, que la forma siempre sigue a la función. Esta es la ley”. (12)

Que como lema del Funcionalismo "la forma sigue a la función" se convirtiera en la parte más conocida de la cita presenta algún problema, porque oculta algunos matices, todos ellos en torno a una noción común. En primer lugar, el fragmento citado muestra que los presupuestos teóricos que participaron en la formación de los principios teóricos del Movimiento Moderno tenían una extracción que sobrepasaba el ámbito meramente arquitectónico: más allá de la validez o no de tales principios (cuestión por lo demás relativamente insoluble), su solidez intelectual (menos discutible) está basada en una 'multidisciplinariedad', que solo en la última época la arquitectura está retomando y que tiene en la filosofía y la economía dos de sus principales componentes. En segundo lugar, el fragmento de Sullivan refuerza la compacidad de la ideología capitalista de mercado: los vínculos que existen entre sus partes son variados y le prestan cohesión; la fortaleza de cualquiera de sus partes se asienta en la de todas las demás.

resuming and that has got both philosophy and economics as its main components. In the second place, the citation by Sullivan strengthens the compactness of market capitalist ideology: links between its parts are multiple and give it cohesion. The strength of each part is underpinned by the strength of everything else.

That inner cohesion is represented in the text by Sullivan by the references to nature and quest for the truth through the universal, which is connected to Kantian idealism through the transcendentalism of Whitman, Thoreau or Emerson. The texts by Sullivan have philosophical entity beyond architectonical practice that not only prefigured the functionalism of 20th century but also presaged the projects by Sullivan himself, though he was still imbedded in the ornamented style which was also prevailing on the other side of the Atlantic Ocean. Moreover, the link between Sullivan and Walt Whitman, the author who previewed (13) better the American identity which shaped the Towers, is not hypothetic or conceptual. Kevin Murphy wrote in an article published by Walt Whitman Quarterly Review: "In an adulatory letter written to Whitman shortly after he had received final approval of his proposals for the Auditorium Building, (14) the young Sullivan confessed to the aging poet that his orbit 'responded to the new attracting sun' and sought Whitman's advice and understanding". (15)

The title of this article is 'Walt Whitman and Louis Sullivan: The Aesthetics of Egalitarianism', which means that Murphy related both with American democracy. That relation is more evident in the poetry of Whitman, but it is more suitable to interpret the approach of Sullivan: built architecture has a massive scope and does not segregate its spectators. Architecture is the most democratic art in terms of an expressive function. (Fig. 3) 
En el caso del escrito de Sullivan, dicha cohesión se puede rastrear a través de las referencias a la naturaleza y la consiguiente búsqueda de la verdad a través de lo universal, lo que a través del trascendentalismo de Whitman, Thoreau o Emerson conduce al idealismo trascendental kantiano. De tal manera, los escritos de Sullivan tienen una entidad filosófica propia más allá de la práctica arquitectónica, que no solo prefiguró el funcionalismo del siglo xx sino que estaba por delante de los propios proyectos del arquitecto de la Escuela de Chicago, aún inmerso cronológica y formalmente en la retórica de la ornamentación, que también seguía vigente al otro lado del Atlántico. Por su parte, el vínculo entre Sullivan y el poeta que mejor prefiguró la identidad estadounidense del siglo de las Torres, Walt Whitman, (13) no es hipotético ni meramente conceptual. En un artículo de la revista Walt Whitman Quarterly Review, Kevin Murphy escribe: "En una carta adulatoria escrita a Whitman poco antes de haber recibido la aprobación final a su propuesta para el Auditorium Building, (14) el joven Sullivan confesó al anciano poeta que su órbita 'respondía al nuevo sol atractor' y buscaba el consejo y la opinión de Whitman”. (15)

El artículo tiene el revelador título de 'Walt Whitman y Louis Sullivan: la estética del igualitarismo', lo que lleva inmediatamente a Murphy a relacionar a ambos con la democracia estadounidense. Esta relación es más evidente en la poesía de Whitman, pero más pertinente es explicarla en la visión de Sullivan: la arquitectura construida tiene un alcance masivo y no hace distingos entre sus espectadores. La arquitectura es la más democrática de las artes en cuanto a su función expresiva. (Fig. 3)

Pero lo verdaderamente revelador de la relación de Sullivan con el trascendentalismo tiene que ver exactamente con lo que aquí se trata, con la síntesis de los dos planos significativos de las Torres, y es un cierto apriorismo en la forma de conocer, una cierta confianza en la intuición a la hora de aprehender las cosas a través de su forma. Se respalde o no filosóficamente esa idea, es cierto que el espectador de la arquitectura rara vez dispone de una gran cantidad de información que podría enriquecer la contemplación de un edi-

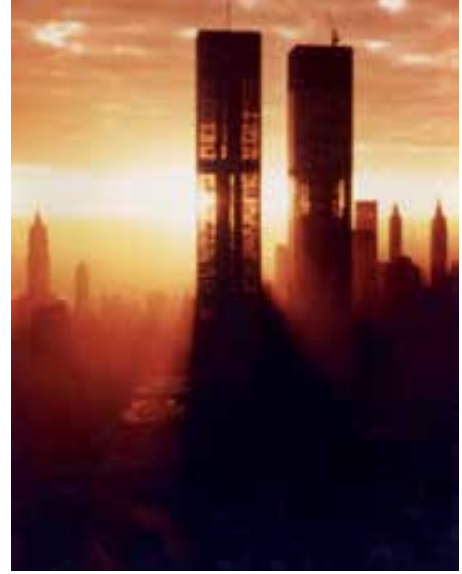

Fig. 3. Las Torres Gemelas durante su construcción.

The relation between Sullivan and transcendentalism links with the synthesis between the two significant levels of the Towers: it is an apriorism about the way of knowing, a certain trust in intuition as a tool to apprehend the reality through its form. Whether or not that idea is philosophically correct, it is undeniable that, in architecture, the spectator rarely has got much information that enriches the contemplation of the building. Whether or not the transcendentalist thesis is true, the spectators often depend on their intuition, so they rely on the transparency of the building, their interpretative accuracy needs the architect to have achieved "that the life is recognizable in its expression". That is the true responsibility of the architect from a functionalist perspective.

That citation ("that the life is recognizable in its expression") has a philosophical relevance and implies that the formfunction dichotomy that fills these paragraphs and its subsequent synthesis are not symmetrical, not balanced, it is resolved in favor of the form precisely because the function exempts it from its own responsibilities according to the modernist logic. By dispossessing it of a merely esthetic purpose, function fills form with a true meaning and, paradoxically, enhances its expressive ability. But this affirmation requires further explanation.

What is being proposed here is that there is a deep misunderstanding about the mechanisms through which the architectonical work means. According to Venturi and part of the subsequent postmodernism, the meaningful ability of the building emanates strictly from the elements added to the structure, whether they be ornamental or stylistic, historicist or regionalist. The hypothesis here is that this is false. That theory calls 'meaning' or 'expressing' to what is really 'dis- 
ficio. Sea verdad o no la tesis trascendentalista, lo cierto es que el espectador de la arquitectura a menudo solo cuenta con su intuición, por lo que está en manos de la transparencia del arquitecto; su precisión interpretativa depende de hasta qué punto el autor de la obra haya conseguido que "la vida sea reconocible en su expresión". Esa es la verdadera responsabilidad del arquitecto desde la perspectiva funcionalista.

Ese "la vida es reconocible en su expresión", por tanto, es la parte más relevante de la cita de Sullivan de 'The Tall Office Building Artistically Considered' desde un punto de vista filosófico. Y es que la dicotomía forma-función que ocupa estos últimos párrafos y su consiguiente síntesis no es simétrica, no está equilibrada; se resuelve a favor de la forma, precisamente porque la función la exime de responsabilidades propias en la lógica de lo moderno, desproveyéndola de un cometido meramente estético, la llena de un sentido pleno y, paradójicamente, potencia su capacidad expresiva. ¿Cuál es el sentido de esta última observación?

Lo que aquí se está afirmando, en realidad, es que hay una profunda incomprensión respecto a los mecanismos a través de los cuales la obra arquitectónica 'significa'. En la visión de Venturi y de parte de la postmodernidad subsiguiente, son los añadidos a la estructura de los edificios, ornamentales y/o estilísticos, historicistas y/o regionalistas, los que tienen mayor capacidad significativa. Aquí se postula que esto es falso. Ese modelo denomina 'significar' o 'expresar' a lo que es más 'encubrir' o 'enmascarar' y tiene como premisa infravalorar la capacidad comprensiva de los espectadores, por una parte, y el nivel inconsciente de la percepción, por otra. Pero es necesario ser muy preciso: no se está cuestionando la capacidad expresiva de elementos sintácticos figurativos (referenciales), sino afirmando la de los abstractos y defendiendo que obedecen a procesos perceptivos que pueden revestir una profundidad y un impacto superiores a las de aquellos. De hecho, (y esto quizá lo entendió el arquitecto bostoniano mejor que sus discípulos más puristas) para Sullivan conseguir un efecto en el espectador era parte irrenunciable de la función de un edificio.

guising' or 'masking', and undervalues in the first place the comprehensive ability of the spectators and in the second place the unconscious facet of perception. But it is necessary a great precision: the last statement does not question the expressive ability of syntactic figurative elements (more referential) but affirms that of abstract ones and advocates that it obeys perceptive processes which can have both superior depth and impact. In fact (and perhaps the Bostonian architect understood this better than his most purist disciples), for Sullivan to create an effect on the spectator was an unwaiverable condition of the function of buildings.

But, what is the difference between the referential postmodernism of the end of the 20th century and the ornament of the 19th? There is something of trompe l'oeil about Postmodernism which there is not about the geometrizing ornament by Sullivan. He wrote: "I should say that it would be greatly for our aesthetic good if we should refrain entirely from the use of ornament for a period of years, in order that our thought might concentrate acutely upon the production of buildings well formed and comely in the nude". (16) Ornament, that Sullivan himself had used, is the esthetic product of the artistic and social concerns at the time. With certain turmoil, Arts \& Crafts identify ornament (an ornament which was more figurative than its predecessors) with a symbiosis between arts and crafts, with artisans recovering their condition of artists (lost because of the Industrial Revolution) and the continuance of art as significative, personal and non-standarized.

The modernist view or architecture, rather than establishing the relation between form and function (as a kind of hierarchy, causality or sequencing such as "forms follows function"), transforms both in facets of the same entity, of the same structure. 
Pero, entonces, ¿cuál es la diferencia entre el postmodernismo referencial de finales del siglo xx y la ornamentación del xix? Hay algo de trampantojo en el postmodernismo que no hay en la ornamentación geometrizante de Sullivan. Contesta éste: "Yo diría que sería muy conveniente para nuestra estética el abstenernos por completo del uso de ornamentos durante varios años, con el fin de que nuestro pensamiento pudiera concentrarse intensamente en la producción de edificios bien formados y convenientes en sí mismos". (16) El ornamento, que el propio Sullivan había utilizado hasta ese momento, es el producto estético de las preocupaciones artísticas y sociales del momento. Con cierta confusión, el movimiento Arts \& Crafts y sus sucesores modernistas identifican ornamento, y un ornamento con más carga figurativa que muchos de sus predecesores, con una simbiosis entre arte y artesanía, con la devolución al artesano de la consideración de artista (consideración cuestionada por la Revolución Industrial) y el mantenimiento del arte en el territorio de la obra significativa, personal y no estandarizada.

La visión moderna de la arquitectura, más que articular la relación entre forma y función (convirtiéndola en alguna suerte de jerarquía, causalidad o la temporalización implícita en "la forma sigue a la función") convierte a ambas en facetas de una misma realidad, de una misma estructura. Más que una 'dependencia' entre forma y función, las palabras clave son 'veracidad', 'coherencia' y 'certidumbre': "El intento de revitalizar el arte de construir bajo las directrices de la forma ha fallado. El esfuerzo de un siglo ha sido malgastado y conduce al vacío. Aquella heroica revolución de hombres extremadamente talentosos tuvo el alcance de una moda. La invención de formas no es obviamente la misión del arte constructivo. El arte constructivo es más y distinto. Su excelente nombre ya deja claro que la construcción es su contenido natural y el arte su culminación. La construcción no solo determina la forma, sino que es la forma en sí misma. Cuando la construcción auténtica encuentra contenidos auténticos, la obra auténtica aparece: una obra genuina y esencial". (17)

La idea de estructura de la Europa continental que Mies distingue de la sajona (la estructura programática frente a la estructura material) aparece aquí

Rather than dependency between form and function, the keywords are truthfulness, coherence and certainty: The attempt to revitalize the building art from the direction of form has failed. A century's worth of effort has been wasted and leads into the void. That heroic revolution of extremely talented men at the turn of the century had the time span of a fashion. The invention of forms is obviously not the task of the building art. Building art is more and different. Its excellent name already makes it clear that building is its natural content and art its completion. Construction not only determines form but is form itself. Where authentic construction encounters authentic contents, authentic works result: works genuine and intrinsic. (17)

The European notion of structure that Mies separated from the Saxon one (programmatic structure versus material structure) appears here in its most relevant meaning: that which emerges from the links between the real and the ideal and that can only be completely understood if related to the Hegelian theory. Its practical offshoot in the United States, in other words, the application of the international style by the American elites, achieved to use that cohesive thesis in their favor despite of the complexity of the philosophical basis of rationalism. (Fig. 4)

Conclusions. Where form does not have its own entity, where it is the result of a structure and its function, then that function takes the floor. A fragment of the criticism by Lewis Mumford towards the Twin Towers says that they were "just glass-and-metal filling cabinets". (18) The situation is the opposite to those buildings with a historic reference, for instance. That Yamasaki wanted to give the Towers the appearance of "filling cabinets" is not reported. Nevertheless, that is what they were: glass-and-metal cabinets filled with factors of production related to tertiary sector. Although deroga- 
con su significado más relevante: aquel que dimana de los vínculos entre lo ideal y lo real, y que solo puede entenderse en toda su extensión relacionándolo con la teoría de Hegel. Sus derivaciones prácticas en los Estados Unidos, es decir, la utilización del Estilo Internacional por las élites capitalistas, lograrían utilizar a su favor esa teoría cohesiva, a pesar de la complejidad del sustrato filosófico del racionalismo. (Fig. 4)

Conclusiones. Cuando no se pretende dar a la forma una entidad propia, cuando ésta se limita a ser el resultado de la función de una estructura, es entonces esa función la que toma la palabra. Parte de la crítica de Lewis Mumford hacia las Torres fue que no eran "más que archivadores de vidrio y metal". (18) La situación es inversa a aquellos edificios en los que existe, por ejemplo, una referencia historicista. No consta que Yamasaki quisiera darle a las Torres la apariencia de archivadores gigantescos y, sin embargo, eso era exactamente lo que eran: clasificadores de factores

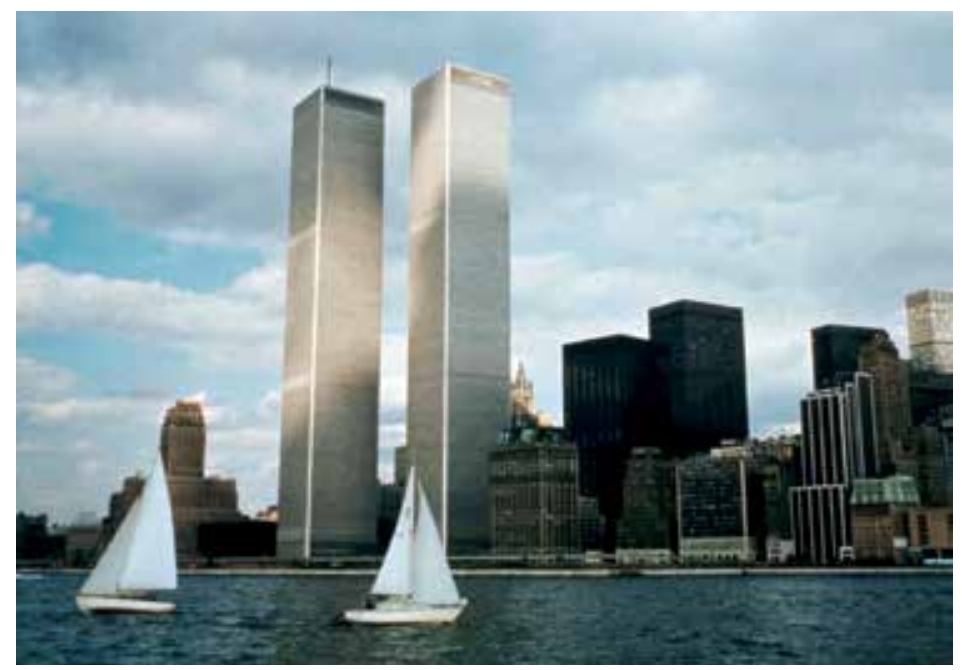

Fig. 4. Las Torres Gemelas desde el río Hudson en la década de los setenta.

tory, Mumford is right because the Towers hide nothing. For him, not a supporter of the Towers, "life was recognizable in its expression". The Towers by Yamasaki collected the functionalist legacy of Sullivan and Mies, but their apparent formal obviousness made them targets for a criticism that identifies the most evidently referential elements with significant ability. That criticism omitted the cultural basis of the Towers and their underlying references. That does not deny the whole postmodernist critique, but the identification between formal abstraction and expressive atrophy.

The significance of the Twin Towers might not operate on the spectator in a conscious manner, but it is also true that that significance implied the whole buildings and not only certain details of their formal solution. That is their value: through their functionalist adscription, the Towers performed a form-function synthesis that achieved to transfer to the economical activities carried out inside them (to its function) qualities such as perfection and sublimity denoted by their form. The fact that this transference operated in a subliminal way (as their critics seem to prove) increases the effectiveness of the message by placing it into the collective unconsciousness of their spectator instead of turning it into an evident proposal subject to debate. The misunderstanding that seems to believe that the machining of buildings proposed by Le Corbusier dehumanized architecture incorporated two complementary misunderstandings: in the first place, because expression in architecture works through mechanisms that do not require referential elements to achieve meaningful expression. In the second place, because the architectural work, being home to human activities, becomes necessarily meaningful, communicating and expressive, and the architect, far from ignoring those meanings, has to stay attentive to them, may they be connotative and indirect, which in any case should enhance and not relax humanistic formation of architecture professionals. 
de producción del sector terciario. Incluso con ánimo peyorativo, la lectura de Mumford es correcta, porque los edificios no ocultan nada. Para Mumford, no precisamente un defensor de las Torres Gemelas, "la vida fue reconocible en su expresión”. Las Torres de Yamasaki recogerían el legado funcionalista de Sullivan y Mies, pero su aparente obviedad formal coadyuvaría a convertirlas en blanco de una crítica que identifica los elementos formales de referencialidad más evidente con la capacidad significativa, obviando el sustrato cultural del minimalismo de las Torres Gemelas y con él las referencias subyacentes a ellas. No se está negando la totalidad de la crítica postmoderna, pero sí su identificación entre abstracción formal y atrofia expresiva.

Quizá la significatividad de las Torres no operara en el espectador en un plano consciente, pero no es menos cierto que esa significatividad implicaba todo lo que el edificio era y no solo determinados detalles de su solución formal. Ese es su valor: a través de su adscripción funcionalista, las Torres operaban una síntesis forma-función que lograba transferir a la actividad económica desarrollada en su interior (su función) las cualidades de perfección y sublimidad denotadas por su forma. Que esta identificación se produjera en un plano subliminal (como parecen atestiguar sus críticos) aumentaría la eficacia de su mensaje, instalándolo en el inconsciente colectivo, en lugar de convertirlo en una propuesta evidente sujeta a debate. El malentendido que parece temer que la maquinización de la obra arquitectónica propuesta por Le Corbusier deshumanizara a la arquitectura, incorporaba dos incomprensiones complementarias: por una parte, la expresión de la arquitectura no opera según mecanismos que impliquen que lo voluntariamente denotativo lo sea de manera auténtica; por otra, porque cada edificio, en cuanto sede inevitable de la actividad humana, va a resultar necesariamente expresivo, comunicador y significante, y el arquitecto, lejos de inhibirse de ello, ha de estar atento a esos significados, en ocasiones más connotativos e indirectos y por tanto más exigentes en su previsión, lo que en todo caso, implicaría potenciar y no relajar la formación humanística de los profesionales de la arquitectura.

\section{NOTAS}

1. Traducido de GOLDBERGER, Paul. The City Observed: New York, A Guide to the Architecture of Manhattan. Nueva York: Random House, 1979.

2. AIA Guide to New York City (1978). En HASKELL, Kari. 'Before \& After; Talking of the Towers. The New York Times, 16 de septiembre de 2001.

3. Traducido de TAURANAC, John. Essential New York. Nueva York: Henry

Holt and Company, Inc. 1979.

4. Traducido de MUMFORD, Lewis. The Pentagon of Power. Nueva York:

Harcourt Brace Jovanovich, 1970, p. 342.

5. VENTURI, Robert. Complexity and Contradiction in Architecture. Nueva York: MOMA, 1966, p. 16.

6. Cuyo exponente más explícito quizá sea Paul Feyerabend.

7. Lo que enlaza con las teorías sobre lugar y percepción de Christian

Norberg-Schulz y Josep Muntañola, entre otros.

8. Quizá no tanto, como se está viendo.

9. Es importante puntualizar que esta caracterización bidimensional se refiere al significado de las Torres y no a la propia naturaleza de éstas. En todo caso, lo que sigue a continuación es la síntesis de ambas, de la misma forma que el edificio supone una síntesis de forma y función.

10. KOOLHAAS, Rem. Delirio de Nueva York. Barcelona: Editorial Gustavo Gili, 2012, p. 173.

11. Si no de forma absoluta, sí en mayor medida que los movimientos previos.

\section{NOTES}

1. GOLDBERGER, Paul. The City Observed: New York, A Guide to the Architecture of Manhattan. New York: Random House, 1979.

2. AIA Guide to New York City, 1978, in HASKELL, Kari. "Before \& After;

Talking of the Towers.” The New York Times, September 16, 2001.

3. TAURANAC, John. Essential New York. New York: Henry Holt and

Company, Inc. 1979.

4. MUMFORD, Lewis. The Pentagon of Power. Nueva York: Harcourt Brace Jovanovich, 1970: p. 342.

5. VENTURI, Robert. Complexity and Contradiction in Architecture. New York: MOMA, 1966: p. 16.

6. Paul Feyerabend may be its most explicit exponent.

7. Which relates to place and time theories such as those by Christian

Norberg-Schulz Josep Muntañola.

8. Maybe not so antithetic, as proved here.

9. This two-dimensional characterization alludes to the meaning of the Towers and not to their nature. In any case, what follows is the synthesis of both, likewise the buildings are a synthesis, almost an identity, between form and function.

10. Translated from KOOLHAAS, Rem. Delirio de Nueva York. Barcelona: Editorial Gustavo Gili, 2012: p. 173.

11. Unless in a larger extent than previous movements. 
12. Traducido de SULLIVAN, Louis H. 'The Tall Office Building Artistically Considered'. Lippincott's Magazine, marzo 1896, p. 408.

13. 'Vid. el poema Estados Unidos a los críticos del Viejo Mundo'. En: WHITMAN, Walt. Hojas de hierba. Barcelona: Galaxia Gutenberg, 2014, pp. 1293-1295.

14. Edificio más alto del mundo de 1889 a 1890 con 72.5 metros. En su decoración interior trabajaría Frank Lloyd Wright, que empezó como delineante en el estudio de Sullivan (WRIGHT, Frank Lloyd. Frank Lloyd Wright: An Autobiography. Petaluma: Pomegranate Communications, 2005, p. 83).

15. Traducido de MURPHY, Kevin. 'Walt Whitman and Louis Sullivan: The Aesthetics of Egalitarianism. Walt Whitman Quarterly Review, 1988, p. 2. 16. 'Louis Sullivan, Ornament in Architecture, 1892'. En FRAMPTON, Kenneth. Historia crítica de la arquitectura moderna. Barcelona: Gustavo Gili, 1993, p. 51.

17. 'Mies van der Rohe.' Traducido de OCKMAN, Joan. Architecture Culture 1943-1968. Nueva York: Rizzoli, 2005, p. 164.

18. MUMFORD, Lewis, $0 p$. cit.
12. SULLIVAN, Louis H. 'The Tall Office Building Artistically Considered'. Lippincott's Magazine, March 1896: 403-409: p. 408.

13. 'Vid. the poem United States to the critics of the Old World'. In: WHITMAN, Walt. Hojas de hierba. Barcelona: Galaxia Gutenberg, 2014, pp. 1292-1294.

14. Tallest building in the world from 1889 to 1890 with 72.5 meters. Frank Lloyd Wright, who started as a draftsman in Sullivan's studio, would work in his interior decoration (WRIGHT, Frank Lloyd, Frank Lloyd Wright: An Autobiography. Petaluma: Pomegranate Communications, 2005: p. 83). 15. MURPHY, Kevin. 'Walt Whitman and Louis Sullivan: The Aesthetics of Egalitarianism'. Walt Whitman Quarterly Review, 1988, p. 2.

16. 'Louis Sullivan, Ornament in Architecture, 1892'. In FRAMPTON, Kenneth. Historia crítica de la arquitectura moderna. Barcelona: Gustavo Gili, 1993, p. 51.

17. 'Mies van der Rohe'. in OCKMAN, Joan. Architecture Culture 1943-1968. New York: Rizzoli, 2005, p. 164.

18. Mumford, Lewis, $O p$. cit.

\section{REFERENCIAS}

AAVV. Comisión de Planificación de la ciudad de Nueva York (ed.). ‘The World Trade Center, an Evaluation'. Nueva York, 1966.

DARTON, Eric. Divided We Stand. Nueva York: Basic Books, 1999.

DAVIDSON, Cynthia. 'Vacío vertical. El perfil perdido de Manhattan'. Arquitectura Viva, 2001. p. 60-63.

FERNÁNDEZ-GALIANO, Luis. 'Yamasaki redux'. Arquitectura Viva, 2001.

p. 36-41.

FRAMPTON, Kenneth. Historia crítica de la arquitectura moderna. Barcelona: Gustavo Gili, 1993.

GIEDION, Sigfried. Espacio, tiempo y arquitectura. El futuro de una nueva tradición. Barcelona: Editorial Científico Médica, 1968.

GILLESPIE, Angus K. Twin Towers: The Life of New York City's World Trade Center. Nuevo Brunswick: Rutgers University Press, 1999.

GOLDBERGER, Paul. The City Observed: New York, A Guide to the Architecture of Manhattan. Nueva York: Random House, 1979.

\section{REFERENCES}

NEW YORK CITY DEPARTMENT OF CITY PLANNING. "The World Trade Center, an evaluation." New York, 1966.

DARTON, ERIC. Divided we stand. New York: Basic Books, 1999.

DAVIDSON, CYNTHIA. "Vacío vertical. El perfil perdido de Manhattan."

Arquitectura Viva, 2001: pp. 60-63.

FERNÁNDEZ-GALIANO, LUIS. "Yamasaki redux." Arquitectura Viva, 2001: pp. 36-41.

FRAMPTON, KENNETH. Historia crítica de la arquitectura moderna. Barcelona: Gustavo Gili, 1993.

GIEDION, SIGFRIED. Espacio, tiempo y arquitectura. El futuro de una nueva tradición. Barcelona: Editorial científico médica, 1968.

GILLESPIE, ANGUS K. Twin Towers: The Life of New York City's World Trade Center. Nuevo Brunswick: Rutgers University Press, 1999.

GOLDBERGER, PAUL. The City Observed: New York, A Guide to the Architecture of Manhattan. Nueva York: Random House, 1979.

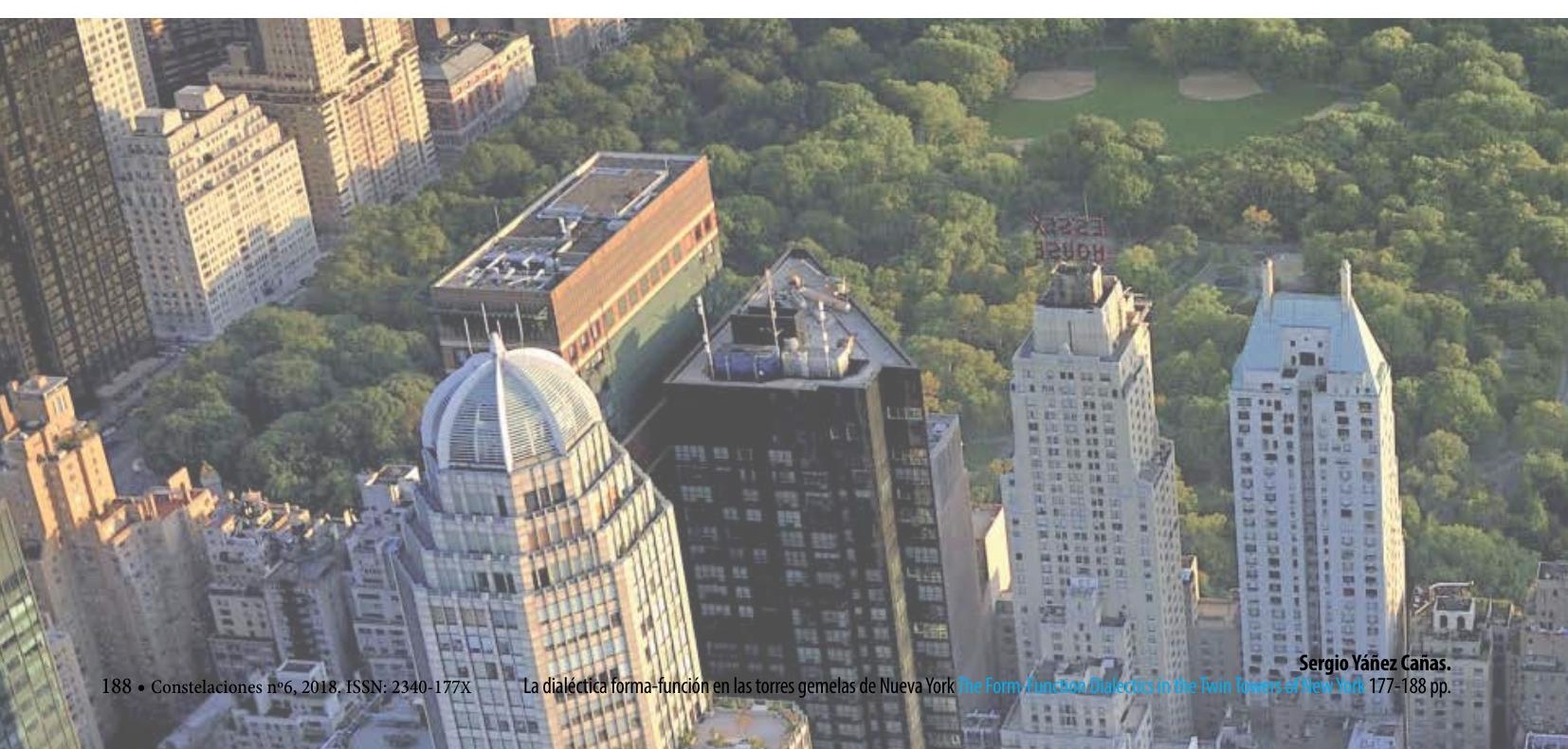


HASKELL, Kari. 'Before \& After; Talking of the Towers. The New York Times, 16 de septiembre de 2001.

HIRT, Sonia, y DIANE, Zahm. The Urban Wisdom of Jane Jacobs. Abingdon: Routledge, 2012.

HUXTABLE, Ada Louise. 'Whose Afraid of the Big Bad Buildings?' The New York Times, 29 de mayo de 1966. pp. 1-14.

JENCKS, Charles. The Language of Post-Modern Architecture. Nueva York: Rizzoli, 1984.

KOOLHAAS, Rem. Delirio de Nueva York. Barcelona: Editorial Gustavo

Gili, 2012.

MALDONADO, Tomás. La speranza progettuale. Turín: Einaudi, 1971. MONTANER, Josep Maria. Arquitectura y crítica. Barcelona: Gustavo Gili, 2013.

MUMFORD, Lewis. La ciudad en la historia. Logroño: Pepitas de Calabaza,

2012.

MURPHY, Kevin. 'Walt Whitman and Louis Sullivan: The Aesthetics of Egalitarianism. Walt Whitman Quarterly Review, 1988. p. 1-15.

NORBERG-SCHULZ, Christian. Los principios de la arquitectura moderna. Barcelona: Reverté, 2005.

RUCHELMAN, Leonard. I. The World Trade Center. Politics and Policies of Skyscrapper Development. Nueva York: Syracuse University Press, 1977. SUDJIC, Dejan. La arquitectura del poder. Barcelona: Ariel, 2007.

SULLIVAN, Louis. H. 'The Tall Office Building Artistically Considered'. Lippincott's Magazine, marzo 1896. pp. 403-409.

TAFURI, Manfredo. Teorías e historia de la arquitectura. Madrid: Celeste, 1997.

VVAA. The Port of New York Authority (ed.). 'A World Trade Center in the Port of New York. 1961.

VENTURI, Robert. Complexity and Contradiction in Architecture. Nueva York: MOMA, 1966.

WHITMAN, Walt. Hojas de hierba. Barcelona: Galaxia Gutenberg, 2014. WRIGHT, Frank Lloyd. Frank Lloyd Wright: An Autobiography. Petaluma: Pomegranate Communications, 2005.
HASKELL, KARI. "Before \& After; Talking of the Towers." The New York Times, September 16, 2001.

HIRT, SONIA, y DIANE ZAHM. The Urban Wisdom of Jane Jacobs. Abingdon: Routledge, 2012.

HUXTABLE, ADA LOUISE. "Whose Afraid of the Big Bad Buildings?" The New York Times, May 29, 1966: pp. 1-14.

JENCKS, CHARLES. The Language of Post-Modern Architecture. Nueva York: Rizzoli, 1984.

KOOLHAAS, REM. Delirio de Nueva York. Barcelona: Editorial Gustavo Gili, 2012.

MALDONADO, TOMÁS. La speranza progettuale. Turín: Einaudi, 1971. MONTANER, JOSEP MARIA. Arquitectura y crítica. Barcelona: Gustavo Gili, 2013.

MUMFORD, LEWIS. La ciudad en la historia. Logroño: Pepitas de calabaza, 2012.

MURPHY, KEVIN. "Walt Whitman and Louis Sullivan: The Aesthetics of Egalitarianism.” Walt Whitman Quarterly Review, 1988: pp. 1-15.

NORBERG-SCHULZ, CHRISTIAN. Los principios de la arquitectura moderna. Barcelona: Reverté, 2005.

RUCHELMAN, LEONARD. I. The World Trade Center. Politics and Policies of Skyscrapper Development. Nueva York: Syracuse University Press, 1977. SUDJIC, DEJAN. La arquitectura del poder. Barcelona: Ariel, 2007

SULLIVAN, LOUIS. H. "The Tall Office Building Artistically Considered." Lippincott's Magazine, marzo 1896: pp. 403-409.

TAFURI, MANFREDO. Teorías e historia de la arquitectura. Madrid:

Celeste, 1997.

THE PORT OF NEW YORK AUTHORITY. "A World Trade Center in the Port of New York." 1961.

VENTURI, ROBERT. Complexity and Contradiction in Architecture. Nueva York: MOMA, 1966

WHITMAN, WALT. Hojas de hierba. Barcelona: Galaxia Gutenberg, 2014. WRIGHT, FRANK LLOYD. Frank Lloyd Wright: An Autobiography. Petaluma: Pomegranate Communications, 2005.

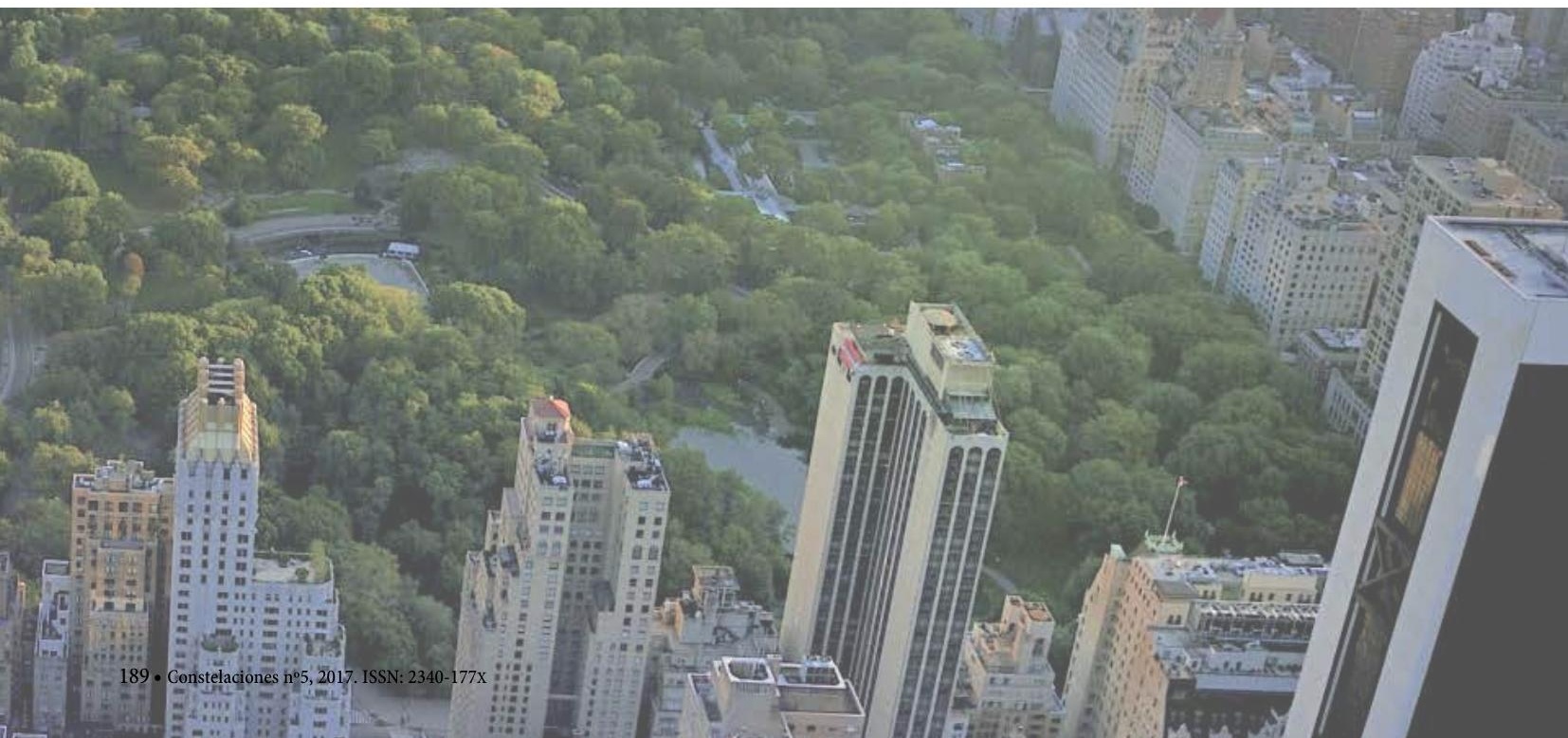


3.

-

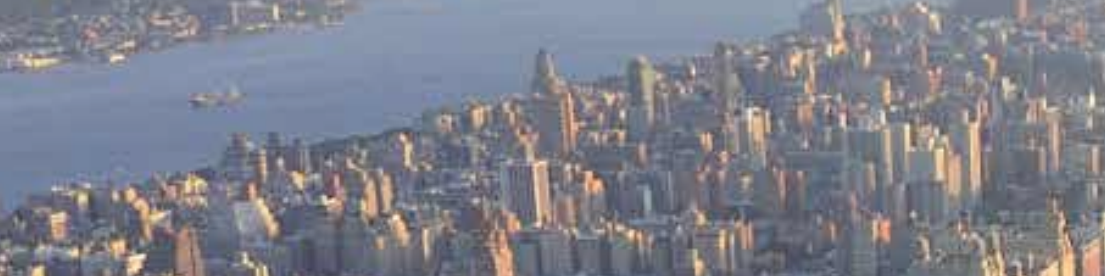

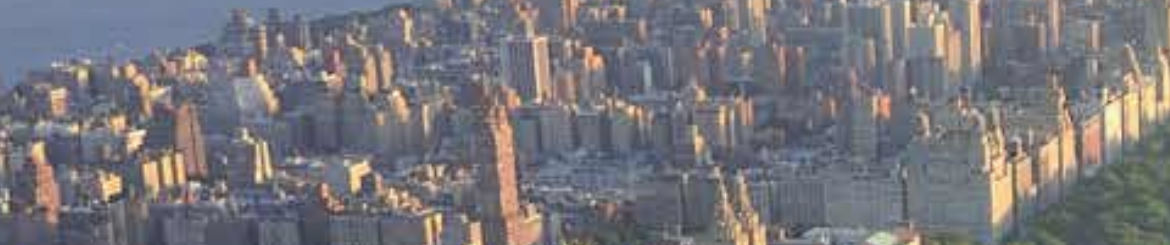
is $\left.\left.n_{1}^{2}\right|^{2}\right|^{2}$

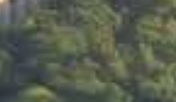

\section{axy 1.}

